近年，筆者らは，ポリエチレンオキシド (PEO)-ポリプロピレンオキシド（PPO）ブロックコポリマー溶液と金属塩溶液を混 合すると，還元剤を添加しなくても，自発的に金属ナノ粒子が形成されることを発見した。すなわち，PEO-PPOブロックコポ リマーが金属イオンの還元剤かつ形成した金属ナノ粒子の効果的な分散安定化剂として機能することを見いだした。本稿では, PEO-PPO ブロックコポリマーによる金属イオン還元機構や形成される金属ナノ粒子のサイズ・形状制御，2種金属複合粒子のワ ンポット合成について紹介する。

\section{1. はじめに}

両親媒性ブロックコポリマーであるポリエチレンオキシド (PEO)-ポリプロピレンオキシド（PPO）ブロックコポリマー (Pluronic $^{\circledR}$, Poloxemerなど, Table 1 ${ }^{1)}$ ) は, 分散安定化剂 2,3), 医療用材料 4-7) , メソポーラス材料合成に扔ける鋳型 8-12) とし て, 広く用いられている。その要因は, PEO-PPO ブロックコポ リマーの両親媒特性やそれらが形成する自己組織体（ミセル， 液晶など), 溶液物性が, 濃度・温度・溶媒・組成などにより 多彩に変化することにある（Fig. 1 ） 13-15)。さらに，筆者らは， 近年, PEO-PPO ブロックコポリマーが金属イオンの還元能を有 することを見いだし，金属塩溶液と PEO-PPO ブロックコポリマ 一溶液を混合するだけで金属ナノ粒子を生成できることを見い だし 16-21)。たとえば，所定濃度のPEO-PPO ブロックコポリマ 一 $\left(\right.$ Pluronic $^{\circledR}, \mathrm{BASF}$ 社製 $)$ 水溶液と塩化金酸 $\left(\mathrm{HAuCl}_{4}\right)$ 水溶 液を混合すると, 室温で $\left[\mathrm{AuCl}_{4}\right]$-が還元され, 金 $(\mathrm{Au})$ ナノ 粒子が形成される。さらに，PEO-PPOブロックコポリマーは， 形成された金ナノ粒子の有効な安定化剂として機能することか ら，形成した金ナノ粒子は，溶液中で高い分散安定性を維持す ることができる。本手法は, 溶媒として水を使用可能, 無毒か つ, すでに医薬材料として実用化されているポリマーを使用, 還元剤不使用, 低エネルギーであることなど, 現代社会が抱え ている環境問題を克服する環境調和型金属ナノ粒子合成法と言 える 22,23)。さらに, 市販の汎用試料を使用している “ready-touse”であること, 単純操作（特別な装置不要）であることな ど, 経済面, 実用面からも今後の発展が期待される。以下に, PEO-PPO ブロックコポリマーによる金属イオンの還元機構や金

受付日：2009年 6 月 23 日 受理日：2009年 9 月 7 日

Amphiphilic Block Copolymers for Nanomaterial Fabrication

Toshio SAKAI $*$,†

*信州大学ファイバーナノテク国際若手研究者育成拠点

長野県長野市若里4-17-1（テ380-8553）

$\dagger$ Corresponding Author, E-mail : tsakai@ shinshu-u.ac.jp
Table 1 Properties of the PEO-PPO block copolymers used in this study ${ }^{1)}$.

\begin{tabular}{crrrrrr}
\hline Pluronic & $\begin{array}{c}\text { Molecular } \\
\text { weight }\end{array}$ & $\begin{array}{c}\text { PEO } \\
\text { wt } \%\end{array}$ & $\begin{array}{c}\text { PPO } \\
\text { block } \\
\text { mol. } \\
\text { weight }\end{array}$ & $\begin{array}{c}\text { PEO } \\
\text { block } \\
\text { mol. } \\
\text { weight }\end{array}$ & $\begin{array}{c}\text { cmc/mM } \\
\left(25^{\circ} \mathrm{C}\right)\end{array}$ & $\begin{array}{c}\text { Nominal } \\
\text { formula }\end{array}$ \\
\hline L43 & 1850 & 30 & 1295 & 555 & - & $E_{60} \mathrm{PO}_{22} \mathrm{EO}_{6}$ \\
\hline L44 & 2200 & 40 & 1320 & 880 & - & $\mathrm{EO}_{10} \mathrm{PO}_{23} \mathrm{EO}_{10}$ \\
\hline L62 & 2500 & 20 & 2000 & 500 & - & $\mathrm{EO}_{6} \mathrm{PO}_{34} \mathrm{EO}_{6}$ \\
\hline L64 & 2900 & 40 & 1740 & 1160 & 26.31 & $\mathrm{EO}_{13} \mathrm{PO}_{30} \mathrm{EO}_{13}$ \\
\hline P65 & 3400 & 50 & 1700 & 1700 & 38.22 & $\mathrm{EO}_{19} \mathrm{PO}_{29} \mathrm{EO}_{19}$ \\
\hline F68 & 8400 & 80 & 1680 & 6720 & 320.5 & $\mathrm{EO}_{76} \mathrm{PO}_{29} \mathrm{EO}_{76}$ \\
\hline P84 & 4200 & 40 & 2520 & 1680 & 6.190 & $\mathrm{EO}_{19} \mathrm{PO}_{43} \mathrm{EO}_{19}$ \\
\hline P85 & 4600 & 50 & 2300 & 2300 & 8.695 & $\mathrm{EO}_{26} \mathrm{PO}_{40} \mathrm{EO}_{26}$ \\
\hline F88 & 11400 & 80 & 2280 & 9120 & 11.51 & $\mathrm{EO}_{103} \mathrm{PO}_{39} \mathrm{EO}_{103}$ \\
\hline P103 & 4950 & 30 & 3465 & 1485 & 0.141 & $\mathrm{EO}_{17} \mathrm{PO}_{60} \mathrm{EO}_{17}$ \\
\hline P104 & 5900 & 40 & 3540 & 2360 & 0.508 & $\mathrm{EO}_{27} \mathrm{PO}_{61} \mathrm{EO}_{27}$ \\
\hline P105 & 6500 & 50 & 3250 & 3250 & 0.461 & $\mathrm{EO}_{37} \mathrm{PO}_{58} \mathrm{EO}_{37}$ \\
\hline F108 & 14600 & 80 & 2920 & 11680 & 3.082 & $\mathrm{EO}_{132} \mathrm{PO}_{50} \mathrm{EO}_{132}$ \\
\hline P123 & 5750 & 30 & 4025 & 1725 & 0.052 & $\mathrm{EO}_{19} \mathrm{PO}_{69} \mathrm{EO}_{19}$ \\
\hline F127 & 12600 & 70 & 3780 & 8820 & 0.555 & $\mathrm{EO}_{100} \mathrm{PO}_{65} \mathrm{EO}_{100}$ \\
\hline 25R4 & 3600 & 40 & 2160 & 1440 & $>10$ wt $\%$ & $\mathrm{PO}_{19} \mathrm{EO}_{33} \mathrm{PO}_{19}$ \\
\hline PEO & 6000 & 100 & 0 & 6000 & - & $\mathrm{EO}_{136}$ \\
\hline & & & & &
\end{tabular}

cmc : critical micellization concentration

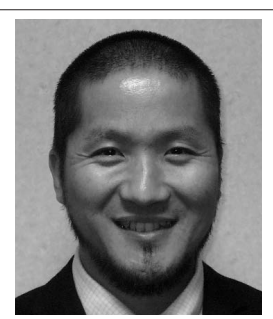

〔氏名〕さかい としお

〔現職]信州大学ファイバーナノテク国際若手 研究者育成拠点助教

〔趣味〕ガーデニング, アイススケート

[経歴〕 2002 年 3 月東京理科大学博士後期課程 修了。2002年 4 月〜 2003 年 6 月(株)コン ポン研究所研究員。2003年7月〜2006 年3月ニューヨーク州立大学バッファ ロー校博士研究員。2006年 4月～2007 年11月東京理科大学総合研究機構プロ ジェクト研究員。2007年12月より現職。 
(A)

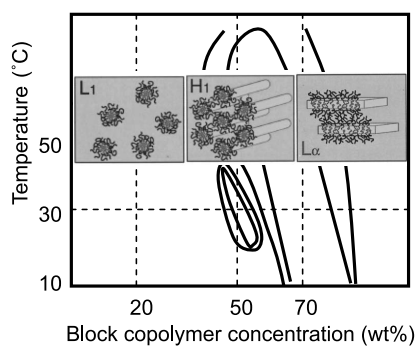

(B)

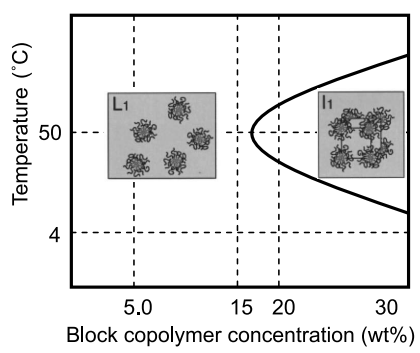

(C)

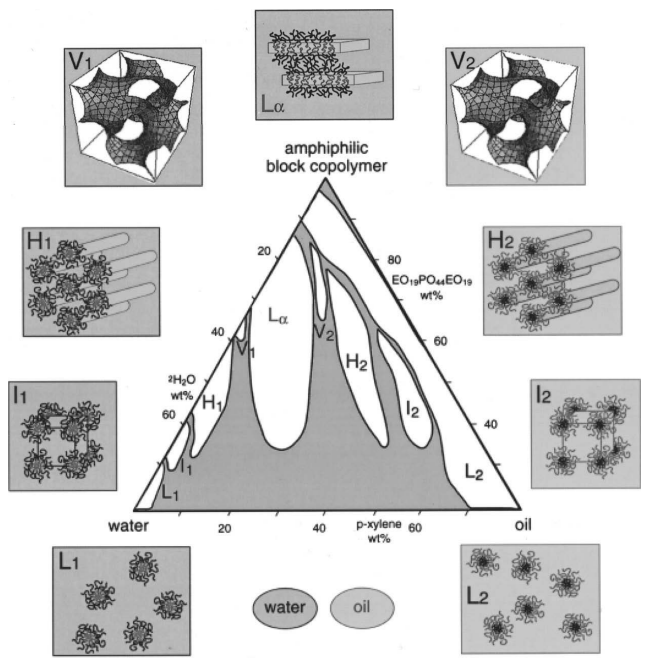

Fig. 1 Phase diagrams of (A) Pluronic L64/water, (B) Pluronic F127/water and (C) Pluronic P84/p-xylene/water systems ${ }^{13-15)}$. The phase boundaries of the one-phase regions are drawn with solid lines. $\mathrm{I}_{1}, \mathrm{H}_{1}, \mathrm{~V}_{1}, \mathrm{~L}_{\alpha}, \mathrm{V}_{2}, \mathrm{H}_{2}$, and $\mathrm{I}_{2}$, denote normal (oil-in-water) micellar cubic, normal hexagonal, normal bicontinuous cubic, lamellar, reverse (water-in-oil) bicontinuous cubic, reverse hexagonal, and reverse micellar cubic lyotropic liquid crystalline phases, respectively, while $\mathrm{L}_{1}$ and $\mathrm{L}_{2}$ denote water-rich (normal micellar) and water-lean/oil-rich (reverse micellar) solutions.

$(\mathrm{Au})$ ナノ粒子, 銀 $(\mathrm{Ag})$ ナノ粒子のサイズ・形状制御, $\mathrm{Au}-$ $\mathrm{Ag}$ 複合化について紹介する。

\section{PEO-PPO ブロックコポリマーを用いた 金属ナノ粒子の合成}

まず，金属ナノ粒子合成にPEO-PPO ブロックコポリマーを使 用した経緯について簡単に述べる。金属ナノ粒子の代表的な湿 式合成法として, 有機溶媒を使用する逆ミセル法 ${ }^{24,25)}$ がある。 この逆ミセル法は, 溶液中で形成する金属ナノ粒子のサイズ . 形状・分散量を高度に制御する方法として広く利用されている が24-29), 溶媒として有機溶媒を使用していることから, 溶媒の水 への転換が求められるようになってきた。水溶媒系での金属ナ ノ粒子の合成では, 一般に, 界面活性剂や水溶性ポリマー水溶 液中に金属塩を溶解して, 還元剤によって金属イオンを還元し て，金属ナノ粒子が調製される22,25,30-35)。金属イオンの還元方法 として, 加熱 22), 光照射30), 超音波照射31) のような外部エネル ギーを印加する場合が多い。それに対して，近年，金属イオン を還元することができる官能基 (とくにアミノ基)を有するポリ マーやデンドリマー (diamine terminated poly (ethylene oxide) ${ }^{33)}$, amine-functionalized third-generation poly (propyleneimine) dendrimers $^{34)}, \alpha$-biotinyl-PEG-block-[poly (2-(N,N-dimethylamino) ethyl methacrylate) ${ }^{35)}$, comb-shaped block copolymer ${ }^{36,37)}$ など) を合成して, 水溶媒系で還元剤を使用しない金属ナノ粒子合成 法が注目され始めた。そこで, 筆者らは, ポリエチレングリコ ール (PEOホモポリマー) が金属イオンと複合化 (polymeric pseudocrown ether- $\left[\mathrm{MCl}_{4}\right]^{-}$complex $)\left(\right.$Fig. 2) ${ }^{38,39)}$ し, 金属イ オンを還元する作用 ${ }^{32)}$ があることに着目して，ポリエチレンオ キシド（PEO）を含むブロックコポリマーであるPEO-PPOブロ ックコポリマーを用いて金属ナノ粒子の湿式合成の検討に着手

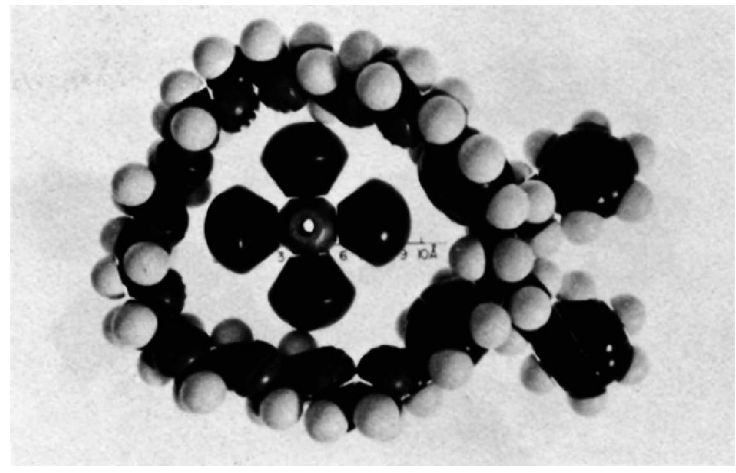

Fig. 2 Polymeric pseudocrown ether- $\left[\mathrm{MCl}_{4}\right]^{-}$complex ${ }^{39)}$.

した。実際に, PEO-PPOブロックコポリマーには金属イオンを 還元する機能があり, PEO-PPO ブロックコポリマー水溶液と塩 化金酸 $\left(\mathrm{HAuCl}_{4}\right)$ 水溶液を混合すると，透明な水溶液がピンク 色へと変化した。このピンク色の水溶液の紫外可視吸収スペク トルを測定すると，金ナノ粒子の表面プラズモン共鳴（SPR） に由来する吸収帯（ピーク波長〜 $540 \mathrm{~nm}$ ）が観測された（Fig. $3)$ 。同時に, $\left[\mathrm{AuCl}_{4}\right]$-由来の吸収帯（ピーク波長 $\left.220 \mathrm{~nm}\right)$ の 減少も確認された (Fig. 3)。このことから, PEO-PPOブロック コポリマーは $\left[\mathrm{AuCl}_{4}\right]$-の還元剤として作用し, 金ナノ粒子を 生成できることが明らかとなった。この反応は室温下で溶液混 合後 2 時間以内に完了することから, PEO-PPO ブロックコポリ マーは $\left[\mathrm{AuCl}_{4}\right]^{-}$の高い還元能, 金ナノ粒子形成作用を有して いることがわかった。ちなみに，PEO-PPOブロックコポリマー と同等の分子量のもつPEOホモポリマー（ポリエチレングリコ ール）を用いて同様の実験を行った場合は，金ナノ粒子形成に は，2日間を必要とした（Fig. 3)。すなわち，PEO-PPOブロッ クコポリマーによる $\left[\mathrm{AuCl}_{4}\right]$-の還元能は, PEOホモポリマー 

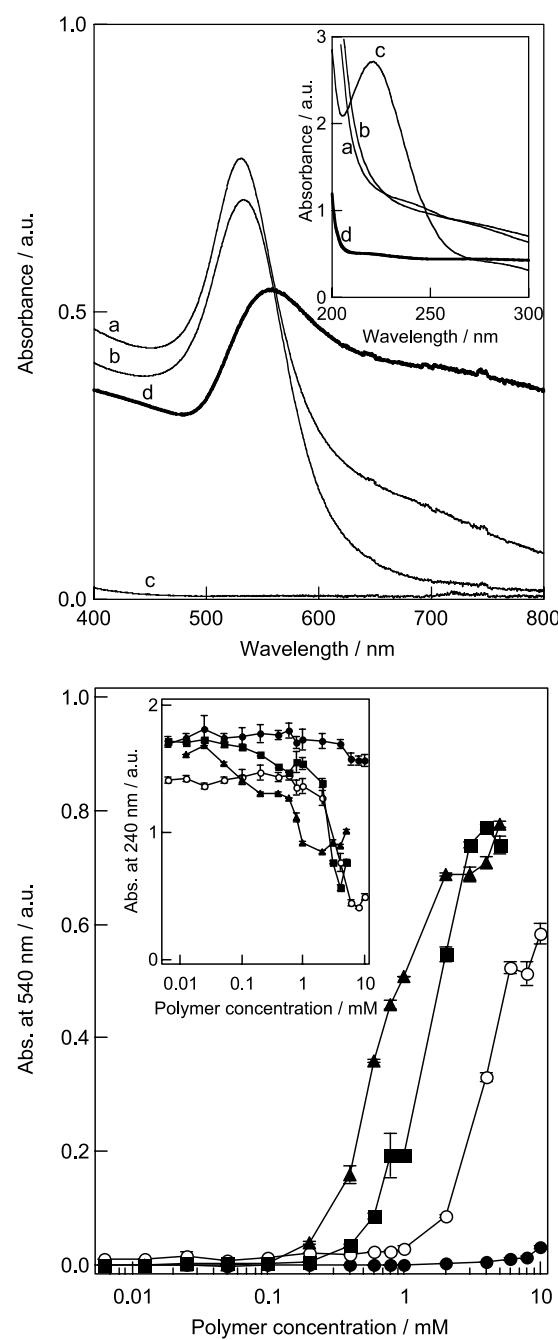

Fig. 3 (Upper panels) Absorption spectra recorded at 2 hours after mixing an aqueous $\left[\mathrm{AuCl}_{4}\right]^{-}$ion solution and a $5.0 \mathrm{mM}$ aqueous Pluronic P103 (a) or F127 (b) block copolymer solution. Also shown for comparison are absorption spectra at (c) 2 hours and (d) 2 days after mixing an aqueous $\left[\mathrm{AuCl}_{4}\right]^{-}$ ion solution and a $5.0 \mathrm{mM}$ aqueous PEO homopolymer solution with $\mathrm{PEO}$ molecular weight intermediate to that of Pluronic P103 and F12716)

(Bottom panels) Absorbances at $\sim 540 \mathrm{~nm}$ at 2 hours after mixing aqueous $\left[\mathrm{AuCl}_{4}\right]^{-}$ion solution and aqueous Pluronic P103 ( $\mathbf{\square})$ or F127 (A) block copolymer solutions, plotted as a function of polymer concentration. Also shown are absorbances at $\sim 540 \mathrm{~nm}$ at 2 hours $(\mathbf{)})$ and 2 days $(\bigcirc)$ after mixing aqueous $\left[\mathrm{AuCl}_{4}\right]^{-}$ion solutions and aqueous PEO homopolymer solutions. The insert shows absorbances at $240 \mathrm{~nm}$ for the same systems and conditions plotted as a function of polymer concentration ${ }^{16)}$.

よりも高いことが明らかとなった。このPEO-PPO ブロックコポ リマーによる $\left[\mathrm{AuCl}_{4}\right]$-の還元能は, PEO-PPOブロックコポリ マー鎖長 (分子量), PEO鎖長, PPO 鎖長が長くなると高くな った（Fig. 4)。長鎖の PEO-PPO ブロックコポリマーは， $\left[\mathrm{AuCl}_{4}\right]$ 一を容易に取り囲み環状複合体 (polymeric pseudocrown ether- $\left[\mathrm{MCl}_{4}\right]^{-}$complex) (Fig. 2) ${ }^{38,39)}$ を形成することができるた めである。この環状複合体は， $\left[\mathrm{AuCl}_{4}\right]$-と $\mathrm{PEO}-\mathrm{PPO}$ ブロック
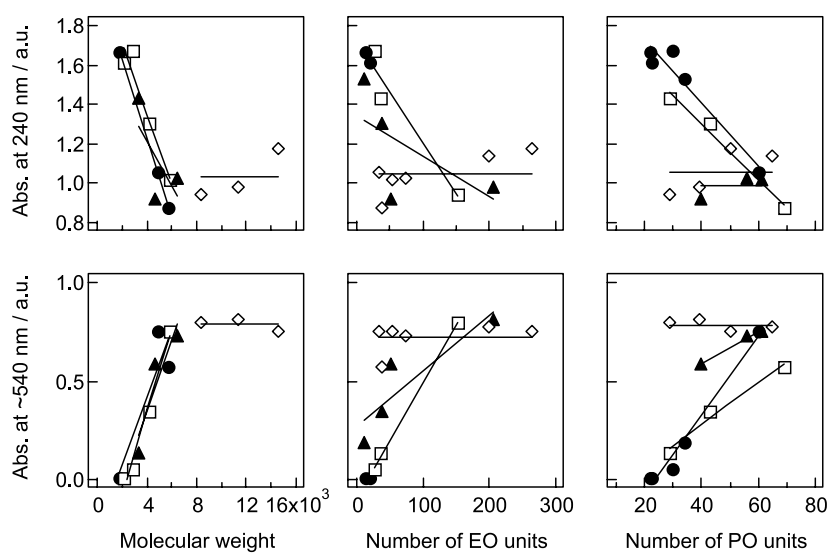

Fig. 4 Absorbances at $240 \mathrm{~nm}$ and $\sim 540 \mathrm{~nm}$ at 2 hours after mixing aqueous $\left[\mathrm{AuCl}_{4}\right]^{-}$ion solution and $5.0 \mathrm{mM}$ aqueous PEO-PPO block copolymer solutions, plotted against the block copolymer molecular weight, number of $\mathrm{EO}$ units and number of $\mathrm{PO}$ units : left-hand-side panel, overall polymer molecular weight at a fixed $\mathrm{PEO} / \mathrm{PPO}$ ratio (L43, $\mathrm{P} 103$ and P123, all with $30 \%$ PEO (O), L44, L64, P84 and P104, all with $40 \%$ PEO ( $\square$ ), P65, P85 and P105, all with $50 \%$ PEO $(\mathbf{\Delta})$, and F68, F88 and $\mathrm{F} 108$, all with $80 \%$ PEO $(\diamond))$; center panel, effect of PEO block length at constant PPO block length (L43 and L44, both PPO block of 1300 MW (O), L64, P65 and F68, all having a PPO block of $\sim 1700 \mathrm{MW}(\square)$, L62, P84, P85 and F88, all having a PPO block of $\sim 2300 \mathrm{MW}(\boldsymbol{\Delta})$, and P103, P104, P105 F108, P123 and F127, all having a PPO block of $\sim 3500 \mathrm{MW}(\diamond))$; right-hand-side panel, effect of PPO block length (L43, L44, L62, L64 and P103, all with PEO block of $<1500 \mathrm{MW}(\mathbf{)})$, P65, P84 and P123, all with PEO block of $\sim 1700 \mathrm{MW}$ $(\square)$, P85, P104 and P105, all with PEO block in the range $2000 \sim 3000 \mathrm{MW}(\boldsymbol{\Delta})$, and F68, F88, F108 and F127, all with PEO block of $>6500 \mathrm{MW}$ $(\diamond))$. The open and closed symbols are connected by dashed and solid lines, respectively ${ }^{18)}$.

コポリマーとのイオンー双極子相互作用により形成される ${ }^{38,39)}$ 。 内包された $\left[\mathrm{AuCl}_{4}\right]$-はPEO, PPOを酸化して，その結果 $\left[\mathrm{AuCl}_{4}\right]$ - が還元されて $\mathrm{Au}^{0}$ となる ${ }^{32)}$ 。このように形成された $\mathrm{Au}^{0}$ は，核を形成し，成長，安定化過程を経て，金ナノ粒子を 形成するものと考えられる (Fig. 5) 16,18)。以下に金ナノ粒子の 形成過程を簡単にまとめる。

核形成（ステップ1）：イオンー双極子相互作用により，PEO$\mathrm{PPO}$ ブロックコポリマーと $\left[\mathrm{AuCl}_{4}\right]^{-}$-が環状複合体 $\left(\left[\mathrm{AuCl}_{4}\right]^{-}\right.$$\left.(\mathrm{PEO}-\mathrm{PPO})_{n}\right)$ を形成して $\left[\mathrm{AuCl}_{4}\right]^{-}$-が還元され ${ }^{32}, \mathrm{Au}^{0}$ クラス ター $\left(\mathrm{Au}^{0}\right)_{m}$ が形成される。

$$
\begin{aligned}
& {\left[\mathrm{AuCl}_{4}\right]^{-}+n(\mathrm{PEO}-\mathrm{PPO}) \rightarrow\left[\mathrm{AuCl}_{4}\right]^{-}-(\mathrm{PEO}-\mathrm{PPO})_{n} \cdots(1)} \\
& {\left[\mathrm{AuCl}_{4}\right]^{-}-(\mathrm{PEO}-\mathrm{PPO})_{n}} \\
& \rightarrow \mathrm{Au}^{0}+4 \mathrm{Cl}^{-}+2 \mathrm{H}^{+}+\text {oxidation products } \\
& m \mathrm{Au}^{0} \rightarrow\left(\mathrm{Au}^{0}\right)_{m}
\end{aligned}
$$

これらの反応にともない生成する酸化物は，アルデヒドやカル ボン酸エステルが含まれているものと考えられる ${ }^{32,40)} 。$ 成長 (ステップ2)：PEO-PPO ブロックコポリマーが $\left(\mathrm{Au}^{0}\right)_{m}$ 表 

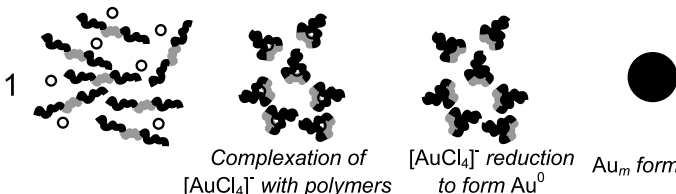

$\left[\mathrm{AuCl}_{4}\right]^{-}$reduction $\mathrm{Au}_{m}$ formation $\left[\mathrm{AuCl}_{4}\right]^{-}$with polymers to form $\mathrm{Au}^{0}$

Step 2
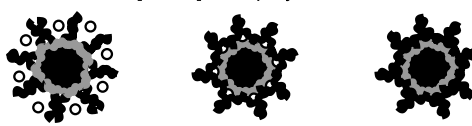

Polymer adsorption Complexation of $\left[\mathrm{AuCl}_{4}\right]$ reduction Particle formation on $\mathrm{Au}_{m} \quad\left[\mathrm{AuCl}_{4}\right]^{-}$with polymers on surface

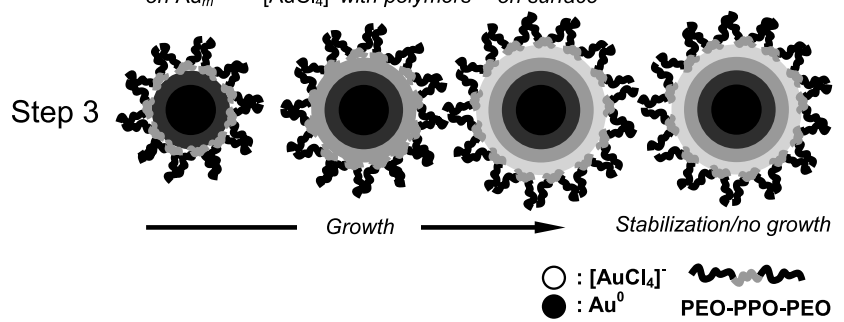

Fig. 5 Schematic of proposed mechanism of $\left[\mathrm{AuCl}_{4}\right]^{-}$ reduction and particle formation ${ }^{18)}$.

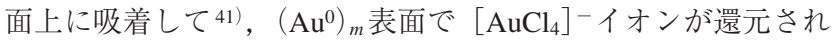
る。結果として，粒子が増大・成長する。

安定化 (ステップ3)：反応の完了にともない，金ナノ粒子表面 への PEO-PPO ブロックコポリマーの吸着により, 金ナノ粒子は 安定化（サイズの固定化・分散安定化）される。

PEO-PPO ブロックコポリマーによる $\left[\mathrm{AuCl}_{4}\right]$-の還元機構に は，以下の (i), (ii) の機構も考えられるが，その寄与は小さ いものと考えられる。

(i) PEO-PPO ブロックコポリマー末端基の水酸基（-OH）がア ルコールとして作用し，金属イオンを還元する 25,42$) 。$

(ii) PEO-PPO ブロックコポリマーのようなポリエーテルは, 溶 存酸素により酸化されてハイドロペルオキシド（ROCOOH） を形成して，金属イオンを還元する42-44)。

つまり，（i），(ii）の機構では，ポリマー末端基のみが $\left[\mathrm{AuCl}_{4}\right]^{-}$-の還元に寄与していることになり，ポリマー鎖長， $\mathrm{PEO}$ 鎖長，PPO鎖長が長いブロックコポリマーほど $\left[\mathrm{AuCl}_{4}\right]$ を還元しやすいという結果（Fig. 4）18）を説明することはでき ない。これは，PEO-PPOブロックコポリマーによる $\left[\mathrm{AuCl}_{4}\right]$ の還元には，ポリマー末端基の還元作用よりも，ポリマー鎖全 体の環状複合体の形成が関与していることを支持している。

\section{3. 金ナノ粒子のサイズ・形状制御}

前項でも述べたように，PEO-PPO ブロックコポリマーによる $\left[\mathrm{AuCl}_{4}\right]$-還元から金ナノ粒子形成には，おもに三つの過程 : 核 形成 (ステップ1), 成長 (ステップ2), 安定化 (ステップ3) が含まれているものと考えられる (Fig. 5) 16,18)。これらのステ ップを自在に制御することができれば，形成する金ナノ粒子の サイズや形状を制御することができるはずである。たとえば, ステップ 1 の核形成過程がステップ 2 の成長過程よりも優先的 に起これば，サイズの小さな粒子が形成されるはずである。そ の反対に, ステップ2の成長過程がステップ 1 の核形成過程よ りも顕著に起これば，粒子サイズは大きくなるはずである。前 述したように, PEO-PPOブロックコポリマー自身の特性（分子
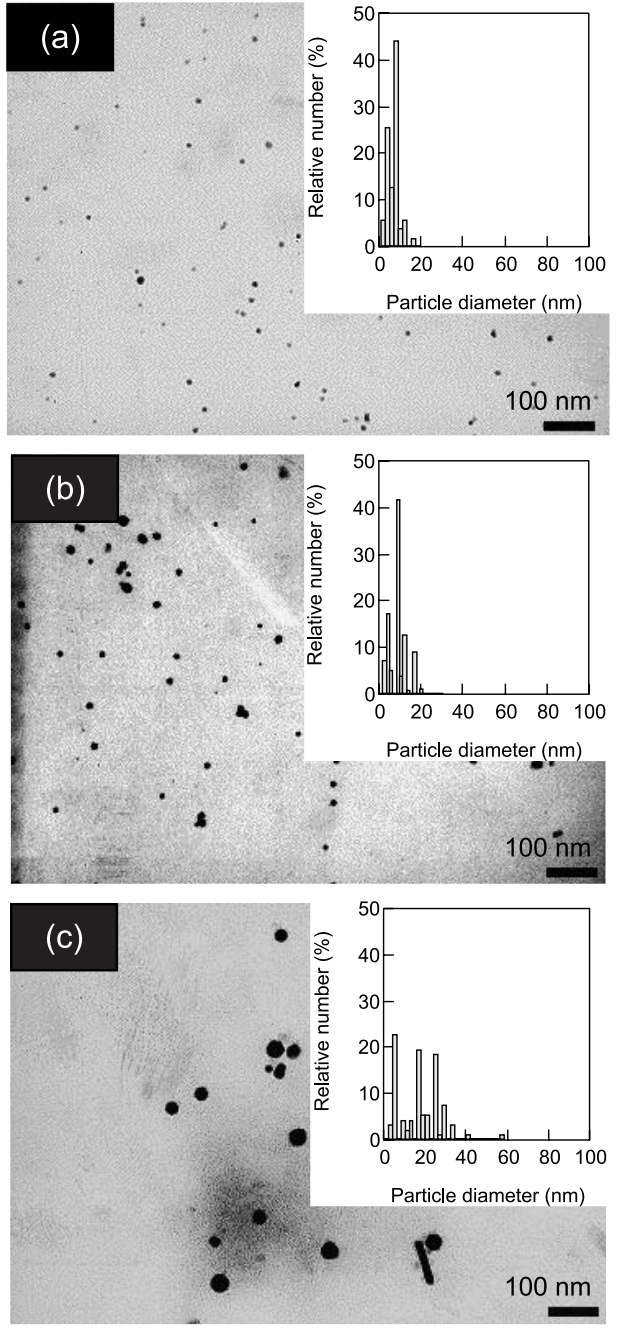

Fig. 6 TEM images and size distributions of gold nanoparticles produced in aqueous solutions at $\mathrm{EO}_{37} \mathrm{PO}_{58} \mathrm{EO}_{37}$ concentration of (a) $0.4 \times 10^{-3}$, (b) $1.0 \times 10^{-3}$ and (c) $5.0 \times 10^{-3} \mathrm{~mol} \mathrm{~L}^{-1} 17$ ).

量や PEO/PPO 比）により, $\left[\mathrm{AuCl}_{4}\right]-$ の還元能や安定化能が異 なることから，それらの機能の違いを利用することにより，ス テップ1，ステップ2，ステップ3を制御することができるはず である。その結果，金ナノ粒子のサイズや形状が制御可能とな ることが期待される。実際に，PEO/PPO比の異なる種々の PEO-PPO ブロックコポリマーを用いて金ナノ粒子を調製したと ころ，形成した金ナノ粒子のサイズは，PEO鎖長の長いポリマ 一ほど大きくなる傾向にあることがわかった。さらに，溶液中 のポリマー濃度，温度，溶媒などにより，形成する金ナノ粒子 のサイズ・形状が大きく変化することも明らかとした。たとえ ば，濃度 $0.4 \mathrm{mM}$ の Pluronic P105（ $\mathrm{EO}_{37} \mathrm{PO}_{58} \mathrm{EO}_{37} ）$ 水溶液中に $\mathrm{HAuCl}_{4}$ 水溶液（反応開始時：0.2 mM）を混合すると，平均粒

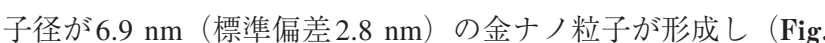
6a)，ブロックコポリマー濃度を $1.0 \mathrm{mM}$ に増加すると，その平


一濃度を $5.0 \mathrm{mM}$ に増加すると平均粒子径が $16.2 \mathrm{~nm}$ （標準偏差 $10.1 \mathrm{~nm}$ ) となった（Fig. 6c）。また，調製温度を $25^{\circ} \mathrm{C}$ から $90{ }^{\circ} \mathrm{C}$ に上昇させると，形成する金ナノ粒子のサイズは大きくなった。 溶媒としてホルムアミドを使用すると，多面体金ナノ粒子が形 

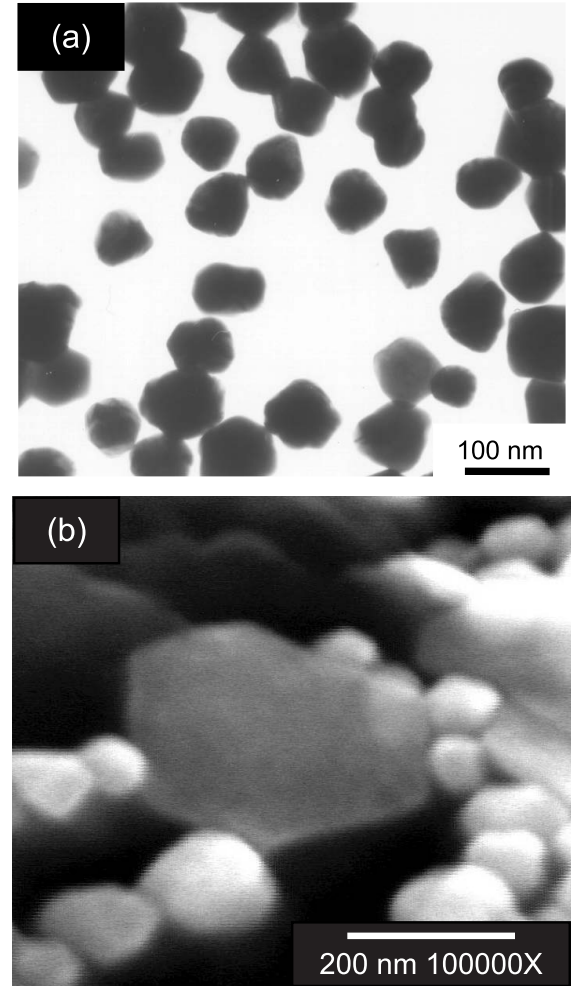

Fig. 7 TEM image of (a) polyhedral gold nanoparticles prepared in $10 \mathrm{wt} \% \mathrm{EO}_{37} \mathrm{PO}_{58} \mathrm{EO}_{37}$ formamide solution at $0.2 \times 10^{-3} \mathrm{~mol} \mathrm{~L}^{-1}\left[\mathrm{AuCl}_{4}\right]^{-}$and SEM image of (b) hexagonal gold nanoplates produced in $5.0 \mathrm{mM} \mathrm{EO}{ }_{37} \mathrm{PO}_{58} \mathrm{EO}_{37}$ aqueous solution at $0.8 \times 10^{-3} \mathrm{~mol} \mathrm{~L}^{-1}\left[\mathrm{AuCl}_{4}\right]^{-17,19)}$.

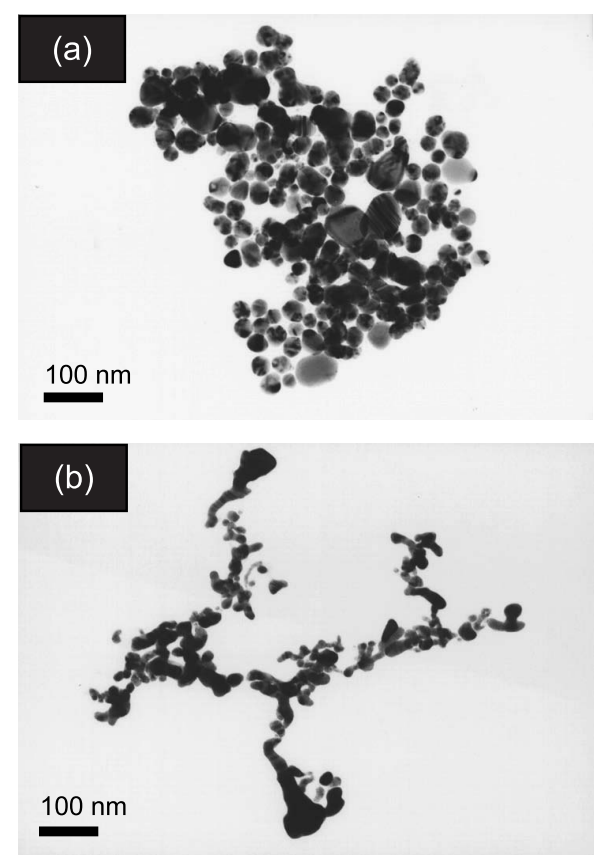

Fig. 8 TEM images of (a) spherical Ag nanoparticles synthesized in $10 \mathrm{wt} \% \mathrm{PO}_{19} \mathrm{EO}_{33} \mathrm{PO}_{19}$ formamide solutions at $0.2 \times 10^{-3} \mathrm{~mol} \mathrm{~L}^{-1} \mathrm{Ag}^{+}$at $\sim 100^{\circ} \mathrm{C}$ for $30 \mathrm{~min}$ and (b) Ag nanowires and networks synthesized in $10 \mathrm{wt} \% \mathrm{EO}_{37} \mathrm{PO}_{58} \mathrm{EO}_{37}$ formamide solutions at $0.2 \times 10^{-3} \mathrm{~mol} \mathrm{~L}^{-1} \mathrm{Ag}^{+}$at $\sim 100{ }^{\circ} \mathrm{C}$ for $30 \mathrm{~min}^{20,21)}$.
成された $($ Fig. $7 \mathrm{a})$ 。さらに, 混合する $\mathrm{HAuCl}_{4}$ 水溶液の濃度を 増加すると, 三角形や六角形の板状粒子が生成することが明ら かとなった (Fig. 7b)。

\section{4. 銀ナノ粒子の合成と金一銀複合粒子の合成}

最後に，銀ナノ粒子の合成と金一銀複合粒子の調製について 紹介する。金ナノ粒子合成の場合と同様に，種々の PEO-PPO ブロックコポリマー水溶液と硝酸銀 $\left(\mathrm{AgNO}_{3}\right)$ 水溶液を混合し て銀ナノ粒子の調製を試みたが，銀ナノ粒子は形成されなかっ た。そこで，溶媒としてホルムアミドを使用して，銀ナノ粒子 の調製を試みた。その結果，銀ナノ粒子が形成され，Pluronic 25R4（ $\mathrm{PO}_{19} \mathrm{EO}_{33} \mathrm{PO}_{19} ）$ ホルムアミド溶液中では，平均粒子径が $30 \mathrm{~nm}$ の球状銀ナノ粒子 (Fig. 8a), Pluronic P105 ( $\left.\mathrm{EO}_{37} \mathrm{PO}_{58} \mathrm{EO}_{37}\right)$
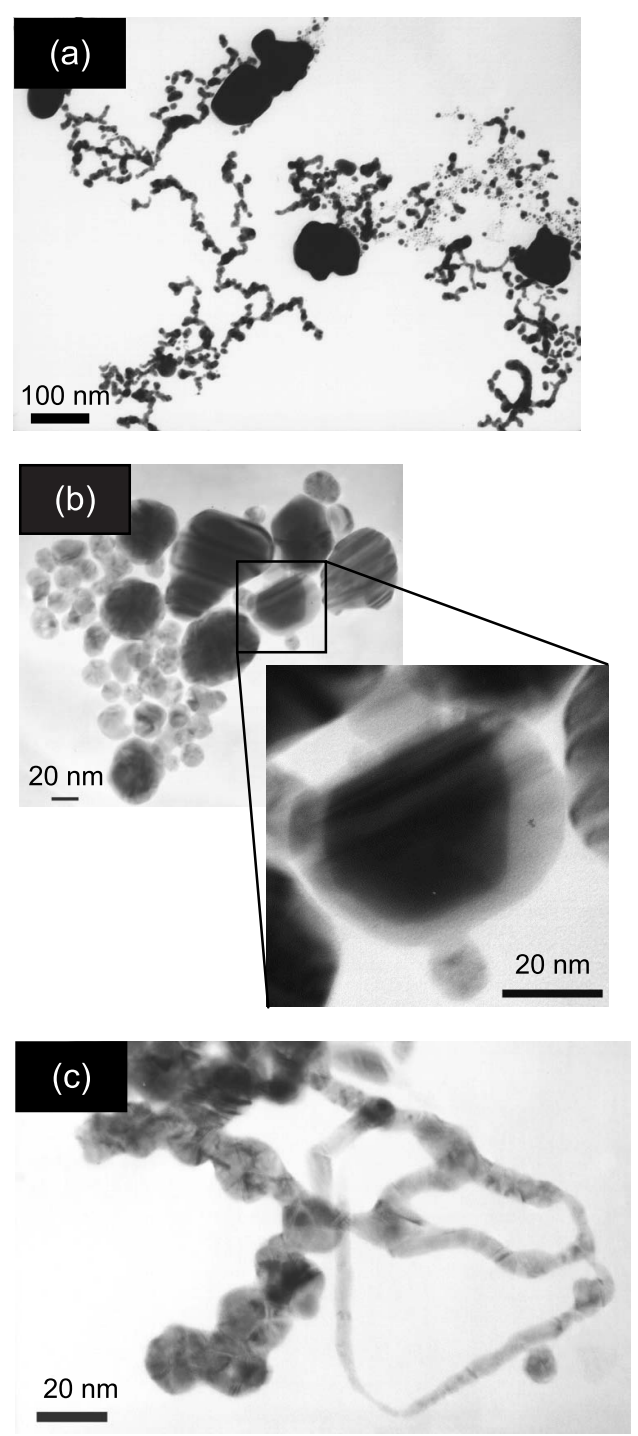

Fig. 9 TEM images of (a) Au particle networked by Ag nanowires synthesized in $20 \mathrm{wt} \% \mathrm{EO}_{37} \mathrm{PO}_{58} \mathrm{EO}_{37}$ formamide solutions at $\sim 100{ }^{\circ} \mathrm{C}$, (b) $\mathrm{Au}-\mathrm{Ag}$ coreshell nanoparticles that coexisted with $\mathrm{Ag}$ nanoparticles synthesized in $20 \mathrm{wt} \% \mathrm{PO}_{19} \mathrm{EO}_{33} \mathrm{PO}_{19}$ formamide solutions at $\sim 100{ }^{\circ} \mathrm{C}$, and (c) Au-networked Ag nanoparticles synthesized in $20 \mathrm{wt} \%$ $\mathrm{PO}_{19} \mathrm{EO}_{33} \mathrm{PO}_{19}$ formamide solutions at $\sim 100{ }^{\circ} \mathrm{C} 20,21$. 
ホルムアミド溶液中では, ナノネットワーク（Fig. 8b）が形成 された。このようなユニークな形状を有する金ナノ粒子，銀ナ ノ粒子分散液に, それぞれ $\mathrm{AgNO}_{3}$ 溶液, $\mathrm{HAuCl}_{4}$ 溶液を添加す ると，銀ナノネットワークにより連結された金ナノ粒子の複合 体 (Fig. 9a), 金/銀一コア/シェル粒子 (Fig. 9b), 金ナノネ ットワークにより連結された銀ナノ粒子の複合体（Fig. 9c) が 形成されることがわかった。このように, PEO-PPO ブロックコ ポリマーの多元特性（金属イオン還元能, 吸着能, 安定化能) を巧みに利用することにより，金属ナノ粒子のサイズ・形状制 御，複合化が可能となる。

\section{5. おわりに}

以上述べてきたように，PEO-PPO ブロックコポリマーには金 属イオンを還元する作用があり，還元剤を使用することなく， 金属塩溶液から金属ナノ粒子を合成できることが見いだされ た。また, ポリマー鎖長や PEO/PPO比, ポリマー濃度, 調製温 度, 溶媒を変化させることにより, 異なるサイズや形状の金属 ナノ粒子を調製できることが明らかとなった。さらには，PEOPPO ブロックコポリマー溶液に異なる金属塩（塩化金酸，硝酸 銀）溶液を逐次添加することにより，異種金属（金一銀）複合 体のワンポット合成が可能であることがわかった。これらの結 果は, ブロックコポリマーのもつ多元特性（金属イオン還元 能, 吸着能, 安定化能) を巧みに利用することにより, 金属ナ ノ粒子のサイズ・形状・複合化を制御可能であることを示して いる。これにより，従来知られている PEO-PPO ブロックコポリ マーの界面化学的特性 (界面活性, 吸着, 自己組織化, 分散安 定化など）に起因したさまざまな可能性に加え，金属ナノ粒子 合成という新しい可能性を提示することができた。現在は， PEO-PPO ブロックコポリマーのもつ界面化学的特性と金属イオ ン還元能を組み合わせて, 一次元, 二次元, 三次元構造体の調 製を試みている。

\section{文献}

1) P. Alexandridis, J. F. Holzwarth, T. A. Hatton : Macromolecules, 27 [9], 2414 (1994).

2) Y. N. Lin, P. Alexandridis : J. Phys. Chem. B, 106 [42], 10834 (2002).

3) T. J. Barnes, C. A. Prestidge : Langmuir, 16 [9], 4116 (2000).

4) L. Yang, P. Alexandridis : Curr. Opin. Colloid Interface Sci., $5[1-2], 132(2000)$

5) A. V. Kabanov, E. V. Batrakova, V. Y. Alakhov : $J$. Controlled Release, 82 [2-3], 189 (2002).

6) F. Ahmed, P. Alexandridis, H. Shankaran, S. Neelamegham : Thromb. Haemostasis, 86 [6], 1532 (2001).

7) D. Cohn, A. Sosnik, A. Levy : Biomaterials, 24 [21], 3707 (2003).

8) G. J. d. A. A. Soler-Illia, E. L. Crepaldi, D. Grosso, C. Sanchez : Curr. Opin. Colloid Interface Sci., 8 [1], 109 (2003).

9) D. Zhao, J. Feng, Q. Huo, N. Melosh, G. H. Fredrickson, B. F. Chmelka, G. D. Stucky：Science, 279 [23], 548 (1998).
10) A. Corma : Chem. Rev., 97 [6], 2373 (1997).

11) Y. Yamauchi, T. Yokoshima, H. Mukaibo, M. Tezuka, T. Shigeno, T. Momma, T. Osaka, K. Kuroda : Chem. Lett., 33 [5], 542 (2004).

12) Y. Yamauchi, T. Ohsuna, K. Kuroda : Chem. Mater., 19 [6], 1335 (2007).

13) M. Malmsten, B. Lindman : Macromolecules, 25 [20], 5440 (1992).

14) P. Alexandridis, D. L. Zhou, A. Khan : Langmuir, 12 [11], 2690 (1996).

15) P. Alexandridis, U. Olsson, B. Lindman : Langmuir, 14 [10], 2627 (1998).

16) T. Sakai, P. Alexandridis : Langmuir, 20 [20], 8426 (2004).

17) T. Sakai, P. Alexandridis : Nanotechnology, 16 [7], S344 (2005).

18) T. Sakai, P. Alexandridis : J. Phys. Chem. B, $109[16]$ 7766 (2005).

19) T. Sakai, P. Alexandridis : Langmuir, 21 [17], 8019 (2005).

20) T. Sakai, P. Alexandridis : Mater. Lett., 60 [16], 1983 (2006).

21) T. Sakai, P. Alexandridis : Chem. Mater., $18[10], 2577$ (2006).

22) P. Raveendran, J. Fu, S. L. Wallen : J. Am. Chem. Soc., $125[46], 13940$ (2003).

23) C. J. Murphy : J. Mater. Chem., 18 [19], 2173 (2008).

24) J. H. Fendler : Nanoparticles and Nanostructured Films, Wiley-VCH : Weinheim (1998).

25) T. Sugimoto : Fine Particles-Synthesis, Characterization, and Mechanisms of Growth, Marcel Dekker, Inc. : New York (2000)

26) M. -C. Daniel, D. Autruc : Chem. Rev., 104 [1], 293 (2004).

27) C. Burda, X. Chen, R. Narayanan, M. A. El-Sayed : Chem. Rev., 105 [4], 1025 (2005).

28） T. K. Sau, C. J. Murphy : J. Am. Chem. Soc., 126 [28], 8648 (2004).

29) C. Ni, P. A. Hassan, E. W. Kaler : Langmuir, 21 [8], 3334 (2005).

30) M. Mandal, S. K. Ghosh, S. Kundu, K. Esumi, T. Pal : Langmuir, 18 [21], 7792 (2002).

31) R. A. Caruso, M. Ashokkumar, F. Grieser : Langmuir, 18 [21], 7831 (2002).

32) L. Longenberger, G. Mills : J. Phys. Chem., 99 [2], 475 (1995).

33) M. Iwamoto, K. Kuroba, V. Zaporojtchenko, S. Hayashi, F. Faupel : Eur. Phys. J. D, 24 [1-3], 365 (2003).

34) X. Sun, X. Jiang, S. Dong, E. Wang : Macromol. Rapid Commun., 24 [17], 1024 (2003).

35) T. Ishii, H. Otsuka, K. Kataoka, Y. Nagasaki : Langmuir, 20 [3], 561 (2004)

36）小林敏勝：表面科学, 26 [2], 107 (2005).

37）石橋秀夫：J. Jpn. Soc. Colour Mater., 79 [6], 251 (2006).

38) S. Yanagida, K. Takahashi, M. Okahara : Bull. Chem. Soc. Jpn., 50 [6], 1386 (1977).

39) A. Warshawsky, R. Kalir, A. Deshe, H. Berkovitz, A. Patchornik : J. Am. Chem. Soc., 101 [15], 4249 (1979).

40) M. Andersson, V. Alfredsson, P. Kjellin, A. E. C. Palmqvist : Nano Lett., 2 [12], 1403 (2002).

41) Y. Lin, P. Alexandridis : J. Phys. Chem. B, $106[42]$, 10834 (2002).

42) P. Barnickel, A. Wokaun : Mol. Phys., $69[1], 1$ (1990).

43) L. M. Liz-Marzan, I. Lado-Tourino : Langmuir, 12 [15], 3585 (1996).

44） L. Wang, X. Chen, J. Zhan, Z. Sui, J. Zhao, Z. Sun : Chem. Lett., 33 [6], 720 (2004). 


\title{
Amphiphilic Block Copolymers for Nanomaterial Fabrication
}

\author{
Toshio SAKAI *,† \\ * International Young Researchers Empowerment Center, Shinshu University \\ 4-17-1 Wakasato, Nagano, Nagano 380-8553, Japan \\ +Corresponding Author,E-mail : tsakai@shinshu-u.ac.jp
}

(Received June 23, 2009 ; Accepted September 7, 2009)

\begin{abstract}
Recently, we found spontaneous formation of metal nanoparticles by simply mixing of metal salt solutions with poly (ethylene oxide)-poly (propylene oxide) (PEO-PPO) block copolymer solutions at ambient temperature in the absence of any other reducing agent. Namely, PEO-PPO block copolymers act in tandem as the reductants for metal ions and stabilizers for metal nanoparticles formed in solutions. This paper introduces the mechanism of metal ion reduction by PEO-PPO block copolymers in solutions, size/shape control of metal nanoparticles formed and one-pot synthesis of bimetallic nanomaterials using PEO-PPO block copolymers in solutions.
\end{abstract}

Key-words : Gold nanoparticles, Silver nanoparticles, Poly (ethylene oxide)-poly (propylene oxide) block copolymers, Metal ion autoreduction, Bimetallic nanomaterials 